\title{
Strategi Peningkatan Kepuasan Kerja Karyawan di PT. Ceva Logistik Indonesia Pekanbaru
}

\author{
Satriardi, Dedi Dermawan, Muhammad Arief Budiman \\ Program Studi Teknik Industri, Fakultas Teknik \\ Universitas Muhammadiyah Riau \\ Jl. Nangka Pekanbaru, Riau \\ E-mail : satriadi@umri.ac.id
}

\begin{abstract}
Abstrak
Dari persamaan regresi diketahui bahwa variabel yang paling dominan mempengaruhi kepuasan kerja karyawan adalah variabel X14(pemberlakuan reward \&punishment) mempunyai pengaruh yang paling besar terhadap kepuasan kerja karyawan yaitu 0,164 diikuti secara berurutan oleh variabel lainnya yaitu variabel X4 (alat-alat kerja yang lengkap) sebesar 0,137; X6 (kebijakan-kebijakan perusahaan) sebesar 0,114; variabel X5 (jam kerja saat ini) sebesar 0,108; variabel X15 (penerapan reward \&punishment yang adil) sebesar 0,107; variabel X13 (rekan kerja menyelesaikan pekerjaan) sebesar 0,061; variabel X2 (sistem penggajian perusahaan) sebesar 0,060; variabel X12 (hubungan antara atasan \& rekan kerja) sebesar 0,041; variabel X7 (kualitas atasan memimpin bawahan) sebesar 0,018; variabel X11 (kerjasama terjalin sesama karyawan) sebesar 0,000; variabel X1 (gaji dibayar sesuai jabatan) sebesar -0,020; variabel X3 (jabatan sesuai pendidikan) sebesar -0,072. Secara simultan atau serentak semua variabel ini berpengaruh terhadap kepuasan kerja karyawan di PT. CEVA Logistik Indonesia Pekanbaru. Variabel yang paling dominan tersebut dapat dijadikan dasar sebagai perumusan strategi.
\end{abstract}

Kata Kunci : Kepuasan kerja, Kinerja karyawan, Regresi linier berganda, SWOT.

\begin{abstract}
From the regression equation in mind that the most dominant variable influencing the jobsatisfaction of employees is variable X14 (enforcement of reward and punishment) have the most influence on job satisfaction of employees i.e 0.164 followed in order variable X4 (working tools is complete) of 0,137; X6 (company policies) of 0.114; X5 (the current working hours) of 0.108; X15(application of reward and punishment is fair) of 0.107; X13 (a co-workerget the job done) of 0.061; X2 (the company's payroll system) of 0.060; X12 (the relationship between supervisor and co-workers) of 0,041; X7(quality supervisor leads thesubordinate) of 0,018; X11 (cooperation contract for fellow employees) of 0,000; XI(salariesare paid accordingthe positions) of -0.020; X3 (the positions of the appropriate education) of -0.072. Simultaneously or synchronously all these variables affect job satisfaction of employees in PT. CEVA Logistics Indonesia Pekanbaru. The most dominant variable that can be reliedupon as a formulation strategy.
\end{abstract}

Keywords: employee performance, job satisfaction, multiple linear regression, SWOT.

\section{Pendahuluan}

Karyawan merupakan pemegang peran utama dalam menjalankan roda kehidupan perusahaan. Apabila karyawan memiliki produktivitas dan motivasi yang tinggi maka akan menghasilkan kinerja dan pencapaian yang baik bagi perusahaan. Sesuai dengan pendapat Malayu S.P Hasibuan (2003:203) mengatakan bahwa: "Kepuasan kerja karyawan merupakan kunci pendorong moral kerja, kedisiplinan dan prestasi kerja karyawan dalam mendukung terwujudnya tujuan perusahaan".

Menurut Melayu S.P. Hasibuan (2001:202) indikator kepuasan kerja dapat diukur dengan tingkat kedisiplinan karyawan dan dapat dilihat dari absensi kehadiran dalam bekerja. Hal ini diperkuat dengan data persentase ketidakhadiran di PT. CEVA Logistik Indonesia dalam periode Januari-Juni 2015 sebagai berikut. 
ISSN: 2354-6751

Tabel 1.

Data Absensi Karyawan PT. CEVA Logistik Indonesia Pekanbaru Jan - Jun 2015

\begin{tabular}{|c|c|c|c|c|c|c|}
\hline $\begin{array}{c}\text { Jenis } \\
\text { Absen }\end{array}$ & Jan & Feb & Mar & Apr & Mei & Jun \\
\hline Izin & 1 & 2 & 2 & 1 & 4 & 2 \\
\hline Sakit & 2 & 1 & 3 & 4 & 5 & 4 \\
\hline Mangkir & 4 & 3 & 2 & 3 & 1 & 3 \\
\hline Cuti & 3 & 4 & 4 & 4 & 2 & 5 \\
\hline $\begin{array}{l}\text { Total } \\
\text { Karyawan }\end{array}$ & 10 & 10 & 11 & 12 & 12 & 14 \\
\hline $\begin{array}{l}\text { Jumlah } \\
\text { Karyawan }\end{array}$ & 30 & 30 & 30 & 30 & 30 & 30 \\
\hline$(\%)$ & 41.7 & 41.7 & 45.8 & 50.0 & 50.0 & 58.3 \\
\hline
\end{tabular}

PT. CEVA Logistik Indonesia Pekanbaru sebagai perusahaan Third Party Logistic (3PL) terkemuka dunia merupakan perusahaan yang bergerak di bidang Contract Logistic dengan PT. Ericsson Indonesia di bidang telekomunikasi. Pernyataan kepuasan terhadap perusahaan dari karyawan juga telah dilakukan wawancara secara langsung dan berikut hasil dari wawancara tersebut dalam bentuk grafik.

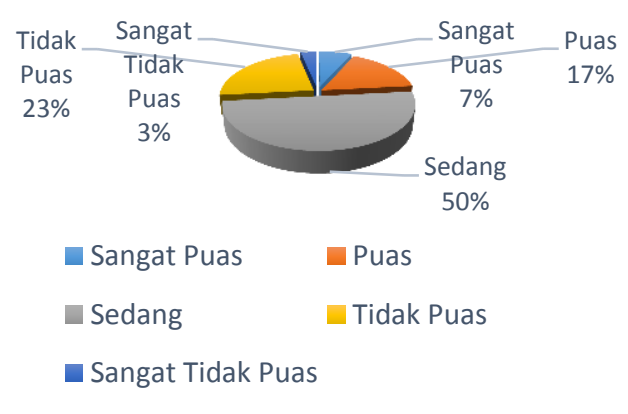

Gambar 1. Pernyataan Langsung Karyawan Perusahaan, 2015

Bertitik tolak uraian diatas bahwa masih rendahnya tingkat kepuasan karyawan terhadap perusahaan, untuk itu perlu diteliti lebih lanjut permasalahan ini dengan mengadakan penelitian dengan judul "Strategi Peningkatan Kepuasan Kerja Karyawan di PT. CEVA Logistik Indonesia Pekanbaru".

\section{Methodologi}

Membahas mengenai hal-hal yang berhubungan dengan penelitian seperti identifikasi masalah, perumusan masalah, tujuan penelitian, pengumpulan data sampai mendapat hasil yang diinginkan dan data-data apa saja yang diperlukan.
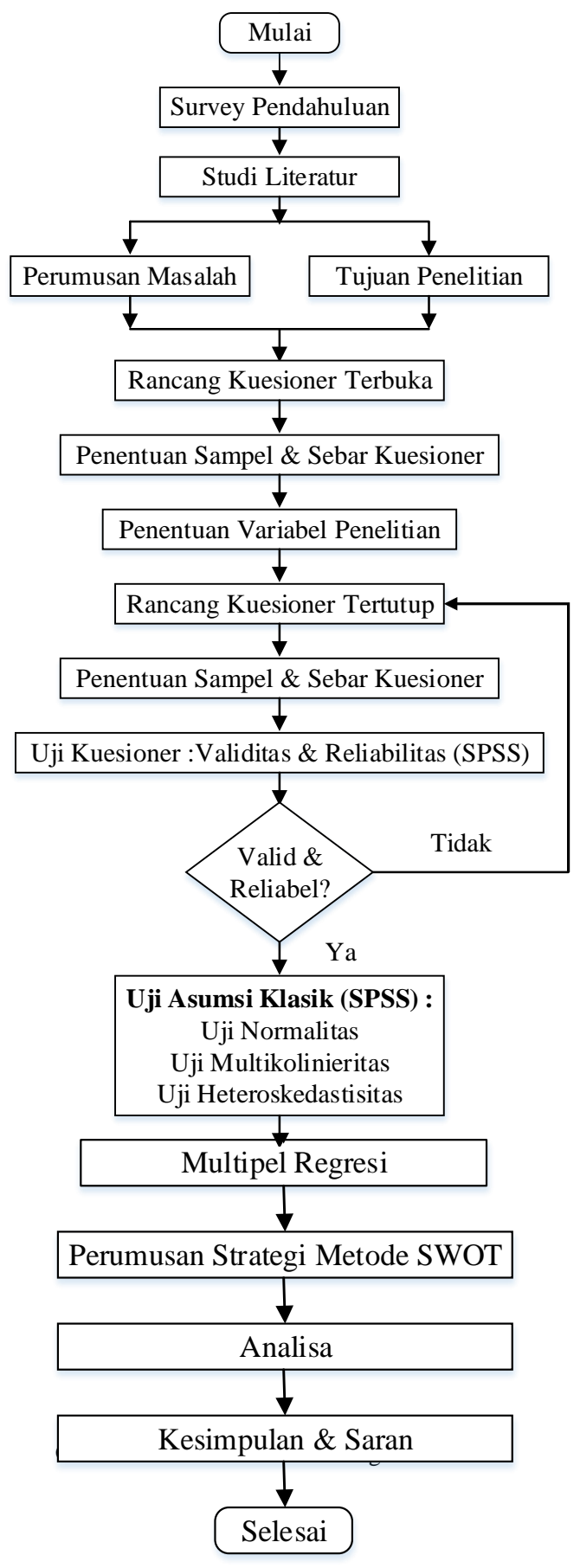

\section{Hasil dan Pembahasan}

Sebelum data dianalisis, berikut keterangan variabel-variabel yang terdapat dalam penelitian ini berdasarkan hasil kuesioner. 
Tabel 2.

Variabel Bebas Hasil Kuesioner Terbuka

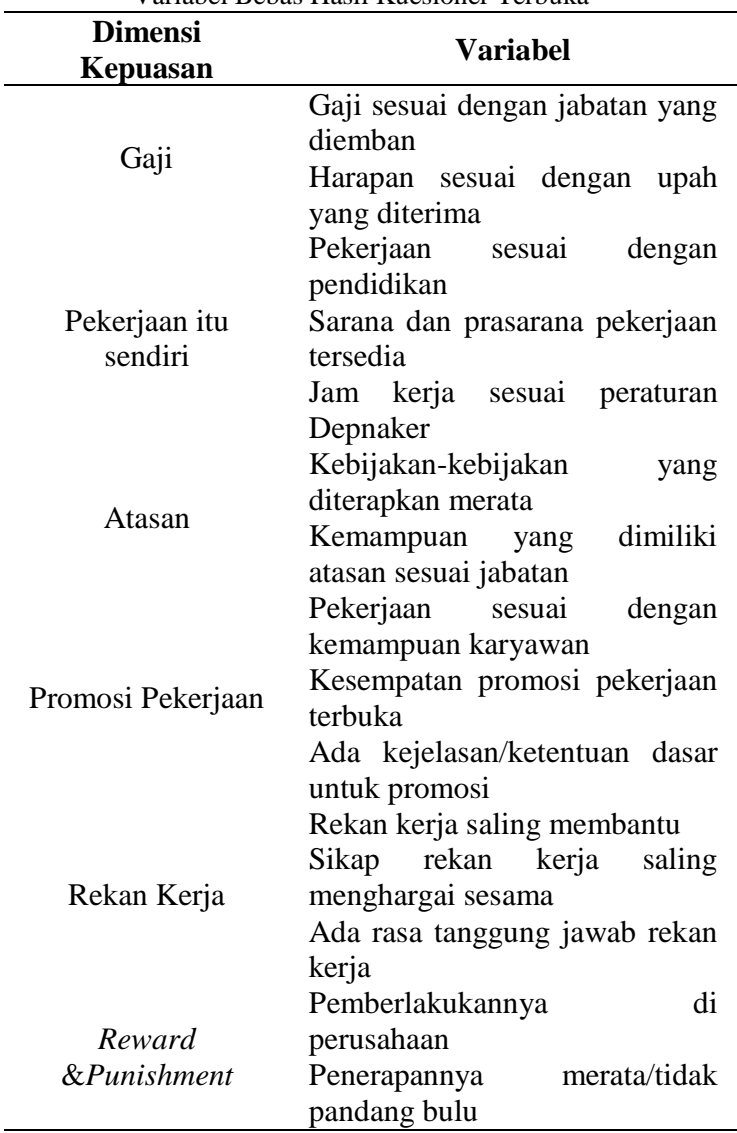

Pada penelitian ini yang menjadi variabel dependen (Y) adalah kinerja karyawan secara keseluruhan terhadap perusahaan. Untuk data tingkat kepuasan berdasarkan kuesioner tertutup dapat dilihat pada tabel dibawah ini.

\subsection{Uji Validitas}

Data kuesioner tertutup yang sudah terkumpul untuk 30 responden diuji validitaskan dengan membandingkan nilai korelasi dengan r-tabel sehingga nilai $r$ tabel dengan $\mathrm{df}=(\mathrm{n}-2)=28$ pada $\alpha=5 \%$ yaitu 0,361 .

Hipotesis :

Ho : Skor butir berkorelasi positif dengan skor faktor (item valid)

H1 : Skor butir tidak berkorelasi positif dengan skor faktor (item tidak valid)

Berdasarkan $r$ hitung dan $r$ tabel, syaratnya :

Ho diterima : jika $\mathrm{r}$ hitung positif dan $\mathrm{r}$ hitung $>\mathrm{r}$ tabel

Ho ditolak : jika $r$ hitung negatif dan $r$ hitung $<r$ tabel.

Dari hasil SPSS didapatkan nilai $r$ hitung setiap item adalah sebagai berikut:
Tabel 3.

Output Uji Validitas

\begin{tabular}{|c|c|c|c|}
\hline Variabel & Korelasi & $r$ tabel & Keterangan \\
\hline X1 & 0,397 & 0,361 & Valid \\
\hline $\mathrm{X} 2$ & 0,728 & 0,361 & Valid \\
\hline $\mathbf{X 3}$ & 0,365 & 0,361 & Valid \\
\hline X4 & 0,851 & 0,361 & Valid \\
\hline X5 & 0,766 & 0,361 & Valid \\
\hline X6 & 0,840 & 0,361 & Valid \\
\hline X7 & 0,459 & 0,361 & Valid \\
\hline X8 & 0,836 & 0,361 & Valid \\
\hline X9 & 0,754 & 0,361 & Valid \\
\hline X10 & 0,827 & 0,361 & Valid \\
\hline X11 & 0,616 & 0,361 & Valid \\
\hline X12 & 0,600 & 0,361 & Valid \\
\hline X13 & 0,448 & 0,361 & Valid \\
\hline X14 & 0,769 & 0,361 & Valid \\
\hline X15 & 0,471 & 0,361 & Valid \\
\hline
\end{tabular}

\subsection{Uji Reliabilitas}

Uji reliabilitas dilakukan untuk mengetahui sejauh mana hasil pengukuran tetap konsisten apabila dilakukan pengukuran dua kali atau lebih terhadap obyek yang sama dengan alat ukur yang sama. Selanjutnya untuk mengetahui reliabilitas dari pertanyaan-pertanyaan dalam kuesioner, digunakan metode perhitungan Cronbach's Alpha.

Tabel 4.

Output Uji Reliabilitas

\begin{tabular}{cc}
\hline Cronbach's Alpha & N of Items \\
\hline .907 & 15 \\
\hline
\end{tabular}




\subsection{Uji Normalitas}

Tabel 5.

Output Uji Normalitas

\begin{tabular}{lccccc}
\hline & N & \multicolumn{2}{c}{ Skewness } & \multicolumn{2}{c}{ Kurtosis } \\
& & \multicolumn{2}{c}{ Std. } & Std. \\
& Statistic & Statistic & Error & Statistic Error \\
\hline Unstandardized & 30 & .133 & .427 & .670 & .833 \\
Residual & & & & & \\
Valid N (listwise) & 30 & & & &
\end{tabular}

Uji normalitas digunakan untuk mengetahui apakah populasi data berdistribusi normal atau tidak. Dari tabel 5.5 dapat diketahui bahwa rasio Skewness $=0,133 / 0,427=0,311$, sedang rasio Kurtosis $=0,670 / 0,833=0,804$. Karena rasio Skewness dan rasio Kurtosis berada diantara -2 hingga +2 , maka dapat disimpulkan bahwa distribusi data adalah normal.

Dari tabel 6 dibawah terlihat bahwa rasio Skewness $=0,133 / 0,427=0,311$, sedang rasio Kurtosis $=0,670 / 0,833=0,804$. Karena rasio Skewness dan rasio Kurtosis berada diantara -2 hingga +2 , maka dapat disimpulkan bahwa distribusi data adalah normal.

\subsection{Uji Multikolinieritas}

Bertujuan apakah didalam model regresi ditemukan adanya pengaruh antar variable independen. Model regresi yang baik tidak terjadi multikolinieritas. Model regresi yang bebas multikolinieritas adalah yang mempunyai nilai toleransi diatas 0,1 atau VIF dibawah 10 (Ghozali, 2005). Jika nilai toleransi dibawah 0,1 dan VIF diatas 10 maka terjadi multikolinieritas dan VIF diatas 10 maka terjadi multikolinieritas.

\subsection{Uji Heteroskadastisitas}

Bertujuan apakah didalam model regresi terjadi ketidaksamaan varian dari residual satu pengamatan ke pengamatan lain tetap, maka disebut homokedastisitas dan jika berbeda disebut heteroskedastisitas (Ghozali, 2005). Salah satu cara untuk mendeteksi ada tidaknya heteroskedastisitas adalah dengan menggunakan uji Glejser. Uji Glejser secara umum dinotasikan sebagai berikut:

$$
|\mathrm{e}|=\mathrm{b} 1+\mathrm{b} 2 \mathrm{X} 2+\mathrm{v}
$$

Dimana :

$$
\begin{array}{ll}
|\mathrm{e}| & =\begin{array}{l}
\text { Nilai absolut dari residual yang } \\
\text { dihasilkan dari regresi model }
\end{array} \\
\mathrm{X} 2 & =\text { Variabel penjelas }
\end{array}
$$

Bila variabel penjelas secara statistik signifikan mempengaruhi residual maka dapat dipastikan

\begin{tabular}{|c|c|c|}
\hline \multirow{2}{*}{ Model } & \multicolumn{2}{|c|}{ Collinearity Statistics } \\
\hline & Tolerance & VIF \\
\hline \multicolumn{3}{|l|}{ (Constant) } \\
\hline $\mathrm{X} 1$ & .174 & 5.749 \\
\hline $\mathrm{X} 2$ & .197 & 5.070 \\
\hline $\mathrm{X} 3$ & .315 & 3.179 \\
\hline $\mathrm{X} 4$ & .004 & 267.225 \\
\hline $\mathrm{X} 5$ & .000 & $2.005 \mathrm{E} 3$ \\
\hline X6 & .011 & 93.541 \\
\hline $\mathrm{X} 7$ & .303 & 3.296 \\
\hline $\mathrm{X} 8$ & .004 & 256.476 \\
\hline X9 & .000 & $2.025 \mathrm{E} 3$ \\
\hline $\mathrm{X} 10$ & .016 & 62.798 \\
\hline $\mathrm{X} 11$ & .283 & 3.531 \\
\hline $\mathrm{X} 12$ & .315 & 3.171 \\
\hline $\mathrm{X} 13$ & .503 & 1.989 \\
\hline X14 & .264 & 3.788 \\
\hline $\mathrm{X} 15$ & .150 & 6.681 \\
\hline
\end{tabular}
model ini memiliki masalah Heteroskedastisitas.

Tabel 6.

Output SPSS Uji Multikolinieritas I

Dapat dilihat pada tabel 6 bahwa terdapat beberapa variabel nilai VIF > 10 sehingga model regresi mengalami multikolinieritas. Artinya model regresi tersebut tidak memenuhi syarat uji regresi linier berganda. Sedangkan variabel < 10 maka dikatakan variabel tersebut tidak terjadi multikolinieritas, artinya model regresi tersebut memenuhi syarat uji regresi linier berganda. Meski demikian, pengujian pada asumsi klasik regresi ini harus diulang kembali hingga seluruh variabel tidak mengalami multikolinieritas.

Untuk pengujian tahap 2 (kedua) variabel yang dibuang adalah yang memiliki nilai VIF paling tinggi yaitu X9 (Promosi pekerjaan transparan diinformasikan)

Dari output SPSS pengujian tahap 3 (ketiga) dapat dilihat bahwa nilai VIF variabel X4 (alat-alat kerja yang lengkap), X6 (kebijakan yang disampaikan atasan), X8 (rolling pekerjaan dari perusahaan), X10 (syarat ketentuan dipromosikan) $>10$, sehingga dilakukan uji lanjutan dengan menghilangkan variabel terbesar yaitu X8 (rolling pekerjaan dari perusahaan), hasilnya dapat dilihat seperti pada data tabel 9

Dari output SPSS pengujian tahap 4 (keempat) dapat dilihat bahwa nilai VIF variabel X6 (kebijakan perusahaan yang disampaikan atasan), X10 (syarat ketentuan dipromosikan) > 10, 
sehingga dilakukan uji lanjutan dengan menghilangkan variabel terbesar yaitu X10 (syarat ketentuan dipromosikan).

\subsection{Analisis Adjusted R Square}

Uji ini dilakukan untuk menentukan proporsi atau persentase total variasi dalam variabel terikat (Y) yang diterangkan oleh variabel bebas (X). Apabila analisis yang digunakan adalah regresi sederhana, maka yang digunakan adalah nilai $\mathrm{R}$ Square. Namun, apabila analisis yang digunakan adalah regresi berganda, maka yang digunakan adalah Adjusted R Square.

\subsection{Perumusan Strategi SWOT}

Analisis SWOT adalah metode perencanaan strategis yang digunakan untuk mengevaluasi kekuatan (strengths), kelemahan (weaknesses), peluang (opportunities), dan ancaman (threats) dalam suatu proyek atau suatu spekulasi bisnis untuk merumuskan strategi perusahaan (F. Rangkuti). Proses pengambilan keputusan strategi selalu berkaitan dengan pengembangan misi, tujuan, strategi, dan kebijakan perusahaan. Dengan demikian perencanaan strategi harus menganalisis faktor-faktor strategi perusahaan (kekuatan, kelemahan, peluang, dan ancaman) dalam kondisi yang ada pada saat ini.

\begin{tabular}{|c|c|c|}
\hline \multirow[b]{2}{*}{ Internal } & Kekuatan (S) & Kelemahan (W) \\
\hline & $\begin{array}{l}\text { 1. Gaji sesuai dengan jabatan } \\
\text { 2. Gaji mengikuti UMR }\end{array}$ & $\begin{array}{l}\text { 1. Pembayaran gaji tidak tepat } \\
\text { waktu } \\
\text { 2. Kesalahan pembayaran upah } \\
\text { Lembur }\end{array}$ \\
\hline Peluang (0) & $\begin{array}{l}\text { Kekuatan Memanfaatkan } \\
\text { Peluang (SO) }\end{array}$ & $\begin{array}{c}\text { Kelemahan dalam } \\
\text { memanfaatkan peluang (W0) }\end{array}$ \\
\hline $\begin{array}{l}\text { 1. Peraturan Gubernur } \\
\text { tentang UMR } \\
\text { 2. Peraturan mengenai kerja } \\
\text { dan upah } \\
\end{array}$ & $\begin{array}{l}\text { Menambah penghasilan } \\
\text { karyawan }\end{array}$ & $\begin{array}{c}\text { Menggunakan teknologi } \\
\text { absensi }\end{array}$ \\
\hline \multirow[t]{2}{*}{ Ancaman (T) } & \multicolumn{2}{|c|}{$\begin{array}{l}\text { Strategi Perbaikan dan Pemecahan Masalah } \\
\text { 1. Meningkatkan perhatian terhadap hak-hak karyawan } \\
\text { 2. Meningkatkan pelayanan informasi kepada karyawan } \\
\text { 3. Memanfaatkan perkembangan informasi teknologi } \\
\text { 4. Menambah penghasilan karyawan }\end{array}$} \\
\hline & $\begin{array}{l}\text { Kekuatan mengatasi ancaman } \\
\text { (ST) }\end{array}$ & $\begin{array}{l}\text { Kelemahan dan hindari } \\
\text { ancaman (WT) }\end{array}$ \\
\hline $\begin{array}{c}\text { Kenaikan harga kebutuhan } \\
\text { pokok }\end{array}$ & $\begin{array}{c}\text { Tingkatkan perhatian terhadap } \\
\text { hak-hak karyawan }\end{array}$ & $\begin{array}{c}\text { Tingkatkan pelayanan } \\
\text { informasi kepada karyawan }\end{array}$ \\
\hline
\end{tabular}

Gambar 2. Matriks SWOT (Gaji/Upah)

\begin{tabular}{|c|c|c|}
\hline & Kekuatan $(\mathbf{S})$ & Kelemahan (W) \\
\hline External & $\begin{array}{l}\text { 1. Pekerjaan sesuai dengan } \\
\text { pendidikan } \\
\text { 2. Sarana dan prasarana } \\
\text { pekerjaan tersedia } \\
\text { 3. Jam kerja sesuai peraturan } \\
\text { Depnaker }\end{array}$ & $\begin{array}{l}\text { 1. Ruang kerja tidak nyaman } \\
\text { 2. WI dan SOP tidak update }\end{array}$ \\
\hline Peluang (0) & $\begin{array}{c}\text { Kekuatan Memanfaatkan } \\
\text { Peluang (SO) }\end{array}$ & $\begin{array}{c}\text { Kelemahan dalam } \\
\text { memanfaatkan peluang (WO) }\end{array}$ \\
\hline $\begin{array}{l}\text { 1. Meningkatnya } \\
\text { kepercayaan customer } \\
\text { 2. Bertambahnya customer }\end{array}$ & $\begin{array}{l}\text { 1. Menambah sarana dan } \\
\text { prasarana pekerjaan } \\
\text { 2. Menambah variasi pekerjaan }\end{array}$ & $\begin{array}{l}\text { 1. Menerapkan standar } 5 \mathrm{~K}+\mathrm{S} \\
\text { 2. Memperbaharui SOP \& WI } \\
\text { Perusahaan }\end{array}$ \\
\hline \multirow[t]{2}{*}{ Ancaman (T) } & \multicolumn{2}{|c|}{$\begin{array}{l}\quad \text { Strategi Perbaikan dan Pemecahan Masalah } \\
\text { 1. Meningkatkan kualitas pekerjaan dengan evaluasi \& inovasi } \\
\text { 2. Memperkuat pengetahuan karyawan dengan training SOP/WI } \\
\text { 3. Membentuk tim } 5 \mathrm{~K}+\mathrm{S} \text { agar ruang kerja nyaman selalu } \\
\text { 4. Menambah perlengkapan sarana \& prasarana bekerja }\end{array}$} \\
\hline & $\begin{array}{l}\text { Kekuatan mengatasi ancaman } \\
\text { (ST) }\end{array}$ & $\begin{array}{l}\text { Kelemahan dan hindari } \\
\text { ancaman (WT) }\end{array}$ \\
\hline $\begin{array}{l}\text { 1. Adanya perusahaan } \\
\text { saingan yang melakukan } \\
\text { pekerjaan yang sama }\end{array}$ & $\begin{array}{l}\text { 1. Tingkatkan kualitas pekerjaan } \\
\text { melalui evaluasi untuk } \\
\text { membenahi kekurangan }\end{array}$ & $\begin{array}{l}\text { 1. Memperkuat pengetahuan } \\
\text { karyawan } \\
\text { 2. Membentuk tim } 5 \mathrm{~K}+\mathrm{S}\end{array}$ \\
\hline
\end{tabular}

Gambar 3. Matriks SWOT (Pekerjaan Itu Sendiri)

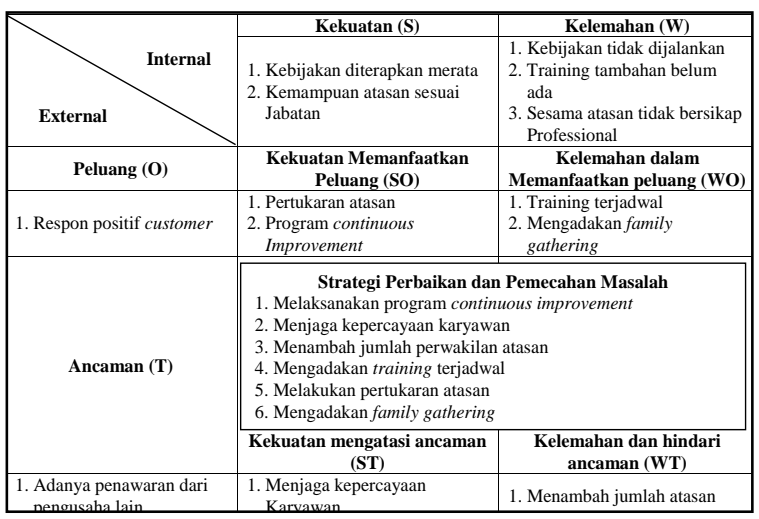

Gambar 4. Matriks SWOT (Atasan)

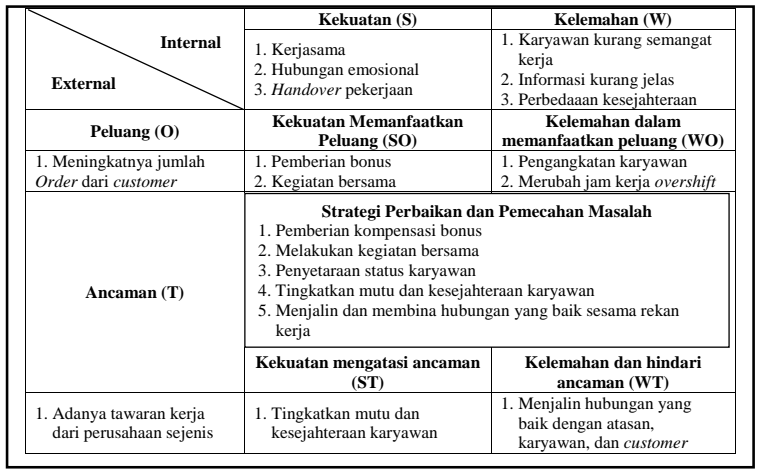

Gambar 5. Matriks SWOT (Rekan Kerja)

\begin{tabular}{|c|c|c|}
\hline \multirow[b]{2}{*}{ External } & Kekuatan (S) & Kelemahan (W) \\
\hline & $\begin{array}{l}\text { 1. Penerapan reward \& } \\
\text { punishment } \\
\text { 2. Keseimbangan antara reward } \\
\text { \&punishment }\end{array}$ & $\begin{array}{l}\text { 1. Tolak ukur belum jelas } \\
\text { 2. Kompensasi tergantung } \\
\text { manajemen pusat }\end{array}$ \\
\hline Peluang $(\mathbf{O})$ & $\begin{array}{c}\text { Kekuatan Memanfaatkan } \\
\text { Peluang (SO) }\end{array}$ & $\begin{array}{c}\text { Kelemahan dalam } \\
\text { memanfaatkan peluang (WO) }\end{array}$ \\
\hline $\begin{array}{l}\text { 1. Image positif di mata } \\
\text { customer dan dunia } \\
\text { logistic }\end{array}$ & $\begin{array}{l}\text { 1. Menyediakan pelatihan yang } \\
\text { memadai untuk semua level }\end{array}$ & $\begin{array}{l}\text { 1. Mengembangkan suatu } \\
\text { program yang jelas, adil dan } \\
\text { tertulis dapat dilaksanakan } \\
\end{array}$ \\
\hline \multirow[t]{2}{*}{ Ancaman (T) } & \multicolumn{2}{|c|}{$\begin{array}{l}\text { Strategi Perbaikan dan Pemecahan Masalah } \\
\text { 1. Memberikan training untuk semua level } \\
\text { 2. Mengembangkan suatu program yang jelas, adil, dan tertulis } \\
\text { 3. Melakukan penegakan hukum/aturan dengan sebaik-baiknya } \\
\text { 4. Melakukan sosialisasi reward \&punishment }\end{array}$} \\
\hline & $\begin{array}{l}\text { Kekuatan mengatasi ancaman } \\
\text { (ST) }\end{array}$ & $\begin{array}{c}\text { Kelemahan dan hindari } \\
\text { ancaman (WT) }\end{array}$ \\
\hline $\begin{array}{l}\text { 1. Adanya perusahaan } \\
\text { sejenis yang } \\
\text { mengedepankan metode } \\
\text { kekeluargaan }\end{array}$ & $\begin{array}{l}\text { 1. Penegakan hukum/aturan } \\
\text { dengan sebaik-baiknya sesuai } \\
\text { dengan norma yang berlaku }\end{array}$ & $\begin{array}{l}\text { 1. Sosialisasi reward \& } \\
\text { punishment kepada seluruh } \\
\text { karyawan diikuti dengan } \\
\text { infomasi kompensasi }\end{array}$ \\
\hline
\end{tabular}

Gambar 6. Matrixs SWOT (Reward \& Punishment)

\section{Simpulan}

Dari penelitian strategi peningkatan kepuasan kerja karyawan di PT.CEVA Logistik Indonesia Pekanbaru maka dapat ditarik kesimpulan sebagai berikut :

a. Hasil identifikasi variabel penelitian yang mempengaruhi kepuasan kerja karyawan di PT. CEVA Logistik Indonesia Pekanbaru adalah variabel X1 (gaji yang dibayar sesuai dengan jabatan), X2 (sistem penggajian di perusahaan), X3 (jabatan saat ini sesuai pendidikan), X4 (alat-alat kerja yang lengkap), X5 (jam kerja 
saat ini), X6 (kebijakan-kebijakan perusahaan), X7 (kualitas atasan memimpin bawahan), X8 (sistem rolling pekerjaan perusahaan), X9 (promosi pekerjaan transparan diinformasikan), X10 (syarat ketentuan untuk promosi), X11 (kerjasama sesama karyawan), X12 (hubungan antara atasan dan rekan kerja), X13 (rekan kerja menyelesaikan pekerjaan), X14 (adanya reward \& punishment), X15 (reward \& punishment yang adil),

b. Pengaruh masing-masing variabel terhadap kepuasan kerja karyawan di PT. CEVA Logistik Indonesia Pekanbaru yaitu, secara parsial variabel X14 (adanya reward \& punishment) mempunyai pengaruh yang paling besar terhadap kepuasan kerja karyawan yaitu 0,167 diikuti secara berurutan oleh variabel lainnya yaitu variabel X15 (reward \& punishment diterapkan dengan adil) sebesar 0,154; X6 (kebijakan-kebijakan perusahaan) sebesar 0,148; variabel X5 (jam kerja saat ini) sebesar 0,122; variabel X3 (jabatan sesuai pendidikan) sebesar 0,085; variabel X13 (rekan kerja menyelesaikan pekerjaan) sebesar 0,076; variabel X8 (rolling pekerjaan perusahaan) sebesar 0,075; variabel X1 (gaji yang dibayar sesuai dengan jabatan) sebesar 0,065 ; variabel X2 (sistem penggajian perusahaan) sebesar 0,052 ; variabel X12 (hubungan antara atasan dan rekan kerja) sebesar 0,044; variabel X11 (kerjasama sesama karyawan) sebesar 0,031; variabel X7 (kualitas atasan memimpin bawahan) sebesar 0,014. Artinya, secara simultan atau serentak semua variabel ini berpengaruh terhadap kepuasan kerja karyawan di PT. CEVA Logistik Indonesia Pekanbaru.

c. Variabel yang sangat dominan mempengaruhi kepuasan kerja karyawan di PT. CEVA Logistik Indonesia Pekanbaru adalah yang memiliki koefisien regresi paling besar yaitu variabel X14 (adanya reward \& punishment).

d. Strategi peningkatan kepuasan kerja karyawan di PT.CEVA Logistik Indonesia Pekanbaru dapat dilakukan dengan hal - hal berikut ini :

o Meningkatkan perhatian terhadap hak-hak karyawan

o Meningkatkan pelayanan informasi terhadap karyawan

o Memanfaatkan perkembangan informasi teknologi

o Menambah penghasilan karyawan

o Meningkatkan kualitas pekerjaan dengan evaluasi \& inovasi

o Memperkuat pengetahuan karyawan dengan training WI dan SOP

o Membentuk tim $5 \mathrm{~K}+\mathrm{S}$

o Menambah perlengkapan sarana dan prasarana bekerja o Melakukan program continuous improvement

o Menjaga kepercayaan karyawan

o Menambah jumlah perwakilan atasan

o Mengadakan training secara terjadwal

o Melakukan pertukaran atasan antar cabang

o Mengadakan family gathering

o Pemberian kompensasi bonus

o Mengadakan kegiatan bersama sebulan sekali

o Penyetaraan status karyawan

o Meningkatkan mutu dan kesejahteraan karyawan

o Merubah jam kerja pergantian shift

o Menjalin hubungan yang baik dengan rekan kerja dan customer

o Memberikan training reward \& punishment untuk semua level

o Mengembangkan suatu program yang jelas, adil, dan tertulis

o Melakukan penegakan hukum/aturan dengan sebaik-baiknya

o Melakukan sosialisasi reward \& punishment kepada karyawan

\section{Saran}

Dari hasil penelitian ini diharapkan perusahaan PT.CEVA Logistik Indonesia Pekanbaru dapat meningkatkan lagi kepuasan kerja karyawannya pada variabel-variabel yang telah teridentifikasi signifikan berpengaruh terhadap kinerja karyawan dan khususnya terhadap variabel yang mempunyai pengaruh paling besar. Hal ini dilakukan agar kinerja karyawan meningkat dan perusahaan mampu bersaing dan merebut pangsa pasar logistik yang lebih luas serta dipercaya oleh customer.

\section{Daftar Pustaka}

[1] Abdul Halim. 2014. Analisis Pengaruh Kualitas Pelayanan Terhadap Kepuasan Konsumen.

[4] Dessler, G. 2000. Manajemen Sumber Daya Manusia. PT. Prenhallindo, Jakarta.

[5] Drs. Danang Sunyoto SH, MM. 2009. Analisis Regresi dan Uji Hipotesis.Cetakan Pertama

[7] Fandy Tjiptono \& Anastasia Diana. 2003. Total Quality Management. Edisi Revisi

[8] Goetsch, D. L \& Davis, S. 1994. Introduction to Total Quality: Quality, Productivity, Competitiveness. Englewood Cliffs, NJ: Prentice Hall International, Inc. 
[9] Ghozali. 2000. Manajemen Sumber Daya Manusia. C.V Andi Offset, Yogyakarta.

[10] Ghozali. 2005. Aplikasi Analisis Multivariate dengan Program SPSS. Badan Penerbit Universitas Diponegoro, Semarang.

[11] Hasibuan, S.P.M. 2003. Manajemen Sumber Daya Manusia. CV Bumi Aksara, Jakarta.

[12] Handoko. 2009. Manajemen Personalia dan Sumber Daya Manusia Edisi 2. Yogyakarta.

[13] Mangkunegara, A.A.A.P. 2004. Manajemen Sumber Daya Manusia Perusahaan. PT. Remaja Rosdakarya, Bandung.

[14] Mangkuprawira, S. dan Vitalaya. 2007. Manajemen Mutu Sumber Daya Manusia. Ghalia Indonesia, Jakarta.

[15] Panggabean, M.S. 2004. Manajemen Sumber Daya Manusia. PT Ghalia Indonesia, Bogor.

[16] Prabu. 2005. Pengaruh Motivasi Kerja, Kepemimpinan dan Budaya Organisasi Terhadap Kepuasan Kerja Karyawan serta Dampaknya pada Kinerja Karyawan. Surabaya.

[17] Rivai, V. 2009. Manajemen Sumber Daya Manusia untuk Perusahaan dari Teori ke Praktek. PT Raja Grafindo Persada, Jakarta.

[18] Rangkuti. 2006. Measuring Customer Satisfaction, Jakarta : Gramedia Pustaka Utama.

[19] Sambas dan Maman Abdurahman. 2007. Analisis Korelasi, Regresi, dan Jalur dalam Penelitian. Bandung : CV Pustaka Setia.

[20] Santoso. 2000. Buku Latihan SPSS Statistik Parametrik, Jakarta : PT. Elex Media Komputindo, Kelompok Gramedia.

[21] Umam, Khaerul. 2010. Perilaku Organisasi. C.V Pustaka Setia, Bandung. 